Tomasz Polak

Uniwersytet im. Adama Mickiewicza

w Poznaniu

tomaszpolak.w@gmail.com
Data przesłania tekstu do redakcji: 11.03.2015

Data przyjęcia tekstu do druku: 03.06.2015

\title{
Kościół rzymski wobec władzy państwowej
}

Abstract: Polak Tomasz, Kościót rzymski wobec władzy państwowej (The Roman Church Against the State Power). "Poznańskie Studia Slawistyczne" 10. Poznań 2016. Publishing House of the Poznan Society for the Advancement of the Arts and Sciences, pp. 25-36 . ISSN 2084-3011.

This article emphasizes the important but rarely analyzed aesthetic-political dimension of the relationship between the Roman Catholic Church and the state. The author synthetically discusses the development of the inner consciousness of the Church of Rome (in its relation to the power) in three nodal epochs: in the Church of Leo the Great and his successors, in the Church of the Gregorian reform and of Innocent III and in the nineteenth-century Church. According to the author's conclusion: it can be shown that the key to understanding the relationship of the Church of Rome to the state power is the phantasmatic belief in the superiority of own ecclesiastical authority over every other power, a belief developed originally in the self-awareness and in the emotional and aesthetic self-emplacement of the great popes of the $5^{\text {th }}$ and $6^{\text {th }}$ centuries.

KEYwORDS: Roman Church; state; power; aesthetics; politics

\section{Wprowadzenie}

Uproszczoną formułę ujmowania różnicy między wschodnio- a zachodniochrześcijańskim rozumieniem relacji Kościoła i państwa sprowadzić można do alteracji: cezaropapizm (Bizancjum i Moskwa) i papocezaryzm (Rzym). To oczywiście nadmierne uproszczenie, jednakże może ono mimo wszystko posłużyć jako wyjściowy klucz do zrozumienia i interpretacji drogi, którą Kościół rzymski wybrał i przebył w swojej relacji do władzy państwowej. Kluczowa teza brzmi: Kościół ten w rdzeniu swojej świadomości (albo też swojego fantazmatu - o czym dalej bardziej szczegółowo) nigdy realnie nie uznał zwierzchności żadnej władzy ziemskiej. Jeśli to „politycznie” czynił (zmuszony okolicznościami), było to najczęściej pragmatyczne, a czasem również formalne uznanie oddzielnych kompetencji władzy państwowej w zakresie, do którego władza kościelna nie rości sobie żadnych pretensji; nigdy zaś uznanie jakichkolwiek 
kompetencji w stosunku do samego Kościoła, sam natomiast wielokrotnie ulegał pokusie przejmowania władzy politycznej, o ile tylko była ona w zasięgu jego eksponentów. Takie ustawienie relacji Kościół - państwo wynika z pewnego wyboru dokonywanego i potwierdzanego wciąż na nowo $\mathrm{w}$ złożonym procesie, począwszy od V stulecia. W procesie tym można wyróżnić pewne „sytuacje węzłowe”, w których mniej lub bardziej wyraźnie ujawnia się istota omawianego wyboru. W moim przekonaniu trzeba wskazać trzy kluczowe momenty:

1) początek samodzielnej drogi politycznej Kościoła rzymskiego w stuleciach V i VI, którego konsekwencją była koronacja cesarza Karola w roku 800 ;

2) usamodzielnienie i oddzielenie administracyjne Kościoła od państwa - poczynając od tzw. reformy gregoriańskiej i sporu o inwestyturę w XI wieku, po dokonane przez Innocentego III na początku XIII wieku (stanowiącego - nie tylko w mojej opinii - prawdziwy początek nowożytności) skuteczne oddzielenie administracji kościelnej od administracji państwowej (cesarskiej);

3) zderzenie słabej władzy kościelnej z rosnącą siłą władzy państwowej od połowy XVIII do połowy XIX stulecia.

Nie oznacza to, że proces kształtowania się relacji Kościół rzymski - struktury państwowe sprowadza się do tych trzech momentów i związanych z nimi procesów, są to jednak sytuacje, w których ujawniły się mentalne podstawy tej relacji i dlatego wyróżniam je w tym artykule. Prezentacja całości procesu, o którym mowa, wymagałaby znacznie obszerniejszego opracowania.

Kluczowy jest pierwszy ze wskazanych węzłów, w którym narodziło się sedno relacji rzymskiego autorytetu kościelnego z władzą. Pozostałe dwa stanowią eksplikację pragmatycznych konsekwencji wewnętrznej (i w moim przekonaniu: nigdy do końca nie poddanej refleksji) decyzji, która zapadła w owym pierwszym kluczowym okresie. Stan dzisiejszy wewnętrznej/sfantazmatyzowanej świadomości Kościoła rzymskiego i jego eksponentów w stosunku do relacji Kościół - państwo jest, jak sądzę, jedynie adaptowanym do zmieniającej się sytuacji politycznej wynikiem procesu zapoczątkowanego i jednoznacznie ukierunkowanego w V stuleciu.

Drogę, którą Kościół rzymski w tej dziedzinie przebył, spróbuję przedstawić, charakteryzując syntetycznie owe trzy węzły - nie wdając 
się w szczegółowe analizy (przekraczające, jak wspomniałem wcześniej, ramy tego artykułu), a raczej wydobywając klucz/klucze, bez których trudno rozumieć obecny stan katolickiej świadomości ,politycznej” i samosytuowanie się Kościoła instytucjonalnego wobec władzy (w szczególności wobec władzy państwowej, ale także wobec kulturowej władzy symbolicznej czy ekonomicznej). Przedstawiając kolejno owe węzły, nakreślę najpierw decydujący o ich wadze splot uwarunkowań politycznych, a następnie ich wymiar estetyczny, by na tym tle przedstawić sedno dokonanych w tych okresach wyborów czy ukierunkowań.

\section{Węzeł pierwszy: zamiana suwerenności po upadku Rzymu cesarskiego}

Jako źródło instytucjonalizacji relacji Kościół - państwo (i to zarówno w odniesieniu do Kościołów wschodnich, jak i Kościoła zachodniego) wskazuje się zazwyczaj procesy zapoczątkowane edyktem o wolności wyznania w Imperium Rzymskim wydanym przez cesarzy Konstantyna (Zachód) i Licyniusza (Wschód) w roku 313 oraz kolejnymi aktami prawnymi dotyczącymi kościelnej hierarchii - w szczególności zaś jej swoistym „upaństwowieniem”, co skutkowało sakralizacją władzy i uprzywilejowaniem stanu duchownego. W Kościele rzymskim instytucjonalnym zwieńczeniem tego procesu były teoretyczne i praktyczne roszczenia uniwersalnego prymatu biskupa Rzymu, sformułowane przez papieża Leona I (rządził Kościołem w latach 440-461), wsparte jego osobistymi zdolnościami przywódczymi i autorytetem teologicznym. To oczywiście istotny proces, ale nie on sam zdecydował o specyfice relacji Kościół - państwo w zachodniej części cesarstwa rzymskiego i w konsekwencji w zasięgu wpływów rzymskiego katolicyzmu. Zadecydowało o tym dołączenie do tego procesu dwóch czynników specyfikujących sytuację duchownych przywódców ówczesnego rzymskiego zachodu:

1) stopniowego upadku suwerenności politycznej, a następnie także kulturowej cesarstwa nad Italią, począwszy od najazdu Hunów, przez królestwa Odoakra i Ostrogotów po królestwo Longobardów;

2) zyskania suwerenności nad tym, co pozostało z Rzymu, przez papieży - najpierw suwerenności „emocjonalnej” czy może psycho- 
społecznej, a następnie stopniowo również politycznej - zwłaszcza między pontyfikatami Leona i Grzegorza I (590-604).

Pierwszy czynnik wydaje się oczywisty: Kościół rzymski stopniowo tracił bezpośrednie odniesienie do władzy imperialnej, zachowując jednak swoją rozwiniętą już imperialną świadomość i wynikające z niej roszczenia. Władcy nowych królestw, tacy jak Odoaker czy Teodoryk, byli z perspektywy takiej samoświadomości Kościoła i jego najwybitniejszych przedstawicieli tylko władcami epizodycznymi, którzy mogli wprawdzie realnie, politycznie zdominować suwerenów kościelnych, a nawet pozbawić ich władzy czy wręcz życia, ale nie mieli w stosunku do nich tytułu zwierzchności. Próbowano wprawdzie zachować powiązanie z cesarzami Wschodu, ale po pierwsze, powiązaniem tym grali zwłaszcza słabsi spośród ówczesnych papieży, po drugie, próby te okazały się ostatecznie nieskuteczne, mimo że do końca VIII stulecia Kościół rzymski akceptował zasadę zatwierdzania papieża przez cesarzy Bizancjum.

Drugi czynnik jest mniej oczywisty, przedstawię go jako własną hipotezę, pokazując zarazem powody, dla których uważam ją za wartą sformułowania i zbadania. W moim przekonaniu czynnik ten zadziałał w połączeniu z pierwszym - szczególnie w przypadku silnych osobowości papieży, takich jak wspomniani Leon i Grzegorz, ale także jak np. Gelazjusz I (483-492) i Feliks III (492-496). Rzecz sprowadza się do sytuacji psychospołecznej, kulturowej i emocjonalnej czy też, ujmując sprawę syntetycznie: „estetycznej” biskupów rzymskich tego czasu. Jej sednem jest narastająca przywódcza samotność biskupów w Italii, a nawet - według nich - w całym chrześcijańskim świecie. Wielu uciekało od samotności, szukając oparcia i umocnienia własnego autorytetu w powiązaniach z cesarzami rzymskiego Wschodu (często także przez udział w rozgrywkach kolejnych władców z patriarchami Konstantynopola), inni zaś, najwybitniejsi, budowali własny autorytet religijny i zarazem polityczny, wprzęgając $\mathrm{w}$ to zadanie owo przywódcze osamotnienie w Italii poddawanej kolejnym najazdom i władztwom, niszczącym imperialny porządek cywilizacyjny i kulturowy. To oni właśnie zdecydowali o trwałym ustawieniu relacji Kościoła do władzy państwowej.

Sposób, w jaki najwybitniejsi eksponenci Kościoła rzymskiego dwóch kluczowych stuleci, o których mowa, odczuwali i przeżywali, a następnie racjonalizowali swoją religijno-polityczną pozycję i konsekwencje 
procesów rozpadu imperium cesarskiego, doprowadzając własną i zbiorową świadomość Kościoła rzymskiego do postaci fantazmatu bezpośredniej reprezentacji Chrystusa - niepoddanej i niemożliwej do poddania żadnej innej władzy, tym bardziej władzy świeckiej - to czynnik, który na potrzeby tej analizy nazywam estetyczno-politycznym.

Warto na moment uruchomić wyobraźnię, by uchwycić składowe owej estetyczno-politycznej sytuacji i jej konsekwencje dla świadomości. Mamy do czynienia z ludźmi, którzy są coraz bardziej odosobnieni jako ostatni przedstawiciele imperium - $\mathrm{i}$ to zarówno w sensie usytuowania politycznego, jak i w sensie ściśle osobowym i kulturowym, a do pewnego stopnia również fizycznym. Obraz tej samotności można uchwycić za pomocą wyobrażenia biskupa pośrodku jego świątyni - bazyliki, w której zasiada jako reprezentant Chrystusa pośrodku zgromadzenia swojego kościoła. Bazylika jest bezpiecznym i jasnym miejscem imperialnej chwały - ale to imperium Chrystusa, nie cesarza. Rozświetlona świątynia skupia zatem blask i moc umierającego imperium (nadając im nowy sens), a poza nią jest świat (ujmując rzecz symbolicznym skrótem) coraz bardziej ciemny i pusty - także za sprawą dewastacji dotychczasowej kultury i cywilizacji. Świątynia jest więc bezwzględną alternatywą dla owego ciemnego świata. Ogniskiem świątyni jest błogosławiąca dłoń Chrystusa Pantokratora, której gest powtarza i reprezentuje dłoń biskupa. Dłoń, która w przekonaniu tych, którzy zbudowali tę świątynię, trzyma czas i wieczność, i każde miejsce ,W niebie, na ziemi i pod ziemią”. Ale owo skupienie boskiej wszechwładzy nad czasem i przestrzenią jest widzialne tylko i właśnie w postaci tej reprezentacji świata, czasu i wieczności, którą jest świątynia i wypełniające ją zgromadzenie Kościoła.

Zorganizowana przestrzeń świątyni jest otoczona świecką przestrzenią; jeżeli przeciwstawia się ona świętości, jest wtedy demoniczna. Dlatego świątynia jako całość przeciwstawia się gwałtownie apokaliptycznej Bestii, z mocą apelując do świata, by także stał się świątynią, do której ma wejść ,,wszystko, co żyje”. (...) [Jest ona - T.P.] jak niebo schodzące na ziemię z ośrodkowym obrazem Chrystusa jako Pantokratora, którego prawica trzyma los wszystkich i każdego z osobna (Evdokimov 1986: 275).

Słowa Evdokimova, wyrastające z ducha, którego ucieleśnieniem były także konstantyńskie bazyliki, dobrze pokazują nie tylko odczuwalny sens wypełnionej „chwałą” świątyni, ale także jej zadanie: ma ona upodobnić 
świat do siebie. Evdokimov mówi o Wschodzie, który zachował rzymską imperialną cywilizację i kulturę. Ten sam obraz świątyni przeniesiony do Italii V stulecia i następnych nabiera kontrastów, których w Bizancjum nigdy w takim stopniu nie doświadczano. Sądzę, że to właśnie symboliczne skupienie religijnego blasku i władzy, wraz z poczuciem politycznej i cywilizacyjnej misji uzasadnionej tylko więzią z Chrystusem, którego papież (i biskupi) są na ziemi wprawdzie tylko „wikariuszami”, jednak wcielającymi i uobecniającymi jego autorytet, zdecydowało o ich wewnętrznym ustawieniu wobec każdej innej władzy. Spójrzmy na dwa charakterystyczne fragmenty mów Leona, wygłaszanych w rocznicę własnego wyboru na biskupa Rzymu i poświęconych tej właśnie godności:

Trwa zatem, co wieczna zarządziła prawda: Piotr święty, w granitowej utwierdzony mocy, steru Kościoła nie wypuszcza z dłoni. Na czoło innych przez Pana wysunięty, nazwany Opoką (Petra), ogłoszony fundamentem, mianowany klucznikiem niebios, postawiony sędzią trybunału, co wydaje wyroki, wiążące i rozwiązujące nawet na żywot wieczny, tyle otrzymuje nazw tajemniczych, aby z samej ich symboliki można było poznać, jak ścisły łączy go związek z Chrystusem. Jeszcze pełniej i potężniej piastuje on swój urząd obecnie. Wszystkie cząstki swego zadania i swej pieczy wykonywa w tym i przez tego, który go wyróżnił. (...) Wobec tego obchód dzisiejszej uroczystości wtedy jest rozumnym hołdem, gdy w mojej niskiej osobie widzi się i czci tego, który łączy w sobie troski wszystkich pasterzów z pieczą nad powierzonymi sobie owcami, i który nawet w niegodnym następcy nic ze swej godności nie traci (Leon I, Mowa trzecia w rocznicę swego wyboru - Leon Wielki 1958: 9).

\section{I w innym miejscu:}

Żyje zaiste w pełni i działa w księciu apostołów owa miłość Boga i ludzi, co nie ulękła się ani lochów więziennych, ani kajdan, ani napaści tłumu, ani gróźb królów. Żyje w nim nadal owa wiara niezłomna, co ani w walce nie ustępowała, ani nie stygła po zwycięstwie (Leon I, Mowa piąta w rocznicę swego wyboru - Leon Wielki 1958: 20).

W kościelnej legendzie Leona szczególną rolę symboliczną odgrywa jego spotkanie z Attylą w Mantui w roku 452, powszechnie przedstawiane jako akt odwagi i politycznej zręczności papieża, który uratował Rzym przed zniszczeniem przez najeźdźców (ale tylko do czasu). Spotkanie to opisywano i przedstawiano w sztuce - od wielkich fresków po książkowe miniatury - tak często i z takim emocjonalno-symbolicznym naciskiem, że uprawnia nas to do traktowania tego momentu jako zewnętrznej - w stosunku do bardziej wewnętrznego i statycznego obrazu świątyni 
wypełnionej „chwałą” - eksplikacji tej właśnie nowej sytuacji estetyczno-politycznej, tym razem w jej dynamicznym wymiarze politycznym. „Leon wobec Attyli” to moim zdaniem eksponowany estetycznie i eksploatowany politycznie symptom rozwiniętego już wewnętrznego fantazmatu kościelnej zwierzchności.

Na tej właśnie podstawie zwracam uwagę na niedostrzegany i niepodejmowany przez badaczy wymiar estetyczno-polityczny wewnątrzświadomościowych decyzji Kościoła rzymskiego o jego (również wewnętrznej) suwerenności w stosunku do jakiejkolwiek świeckiej władzy - decyzji, których pierwszym emblematycznym uosobieniem był Leon, a kolejnymi jego wybitni następcy aż po Grzegorza I. Tymczasowym przerwaniem i zamknięciem tego procesu uwewnętrznienia suwerenności Kościoła stała się w roku 800 koronacja Karola Wielkiego przez papieża Leona III, który najpierw uciekł pod opiekę przyszłego cesarza do Akwizgranu, w Rzymie bowiem jego władza i życie były zagrożone z powodu buntu części arystokracji i kleru, a następnie wrócił z Karolem, ukoronował go na cesarza Zachodu i uznał jego polityczną jurysdykcję nad Rzymem, zapoczątkowując okres układania się władzy kościelnej z nową władzą cesarską (i koncesji dla niej), zakończony drugim z węzłowych momentów, na które zwracam tu uwagę, czyli ostatecznym rozdzieleniem administracji kościelnej i państwowej, zapoczątkowanym tzw. reformą gregoriańską, a doprowadzonym do końca za pontyfikatu Innocentego III (1198-1216).

\section{Węzeł drugi: rozdzielenie administracji}

Jak w przypadku pierwszego ,węzła”, mamy tu do czynienia z podobną sytuacją historiograficzno-interpretacyjną: większość badaczy późnośredniowiecznych relacji Kościół - państwo (zwłaszcza historyków kościelnych) skupia uwagę przede wszystkim na tzw. sporze o inwestyturę i porządkowaniu jurysdykcji kościelnej (najpierw w konflikcie papieża Grzegorza VII z cesarzem Henrykiem IV, a także w rodzących się z tej samej przyczyny konfliktach władców krajowych z lokalnymi biskupami - jak króla Bolesława Śmiałego z biskupem Stanisławem ze Szczepanowa w Polsce czy króla Henryka II z Thomasem Becketem w Anglii, a następnie w kluniackiej reformie i konsolidacji stanu duchownego - cf. 
Knowles, Obolensky 1988: 175-181). Trwałość i skuteczność zapoczątkowanego wówczas procesu przebudowy struktur kościelnych i ich relacji do struktur państwowych zapewniły jednakże działania mniej spektakularne, a o wiele silniej umocowane w nowej mentalności i nowej estetyce politycznej Kościoła rzymskiego rozwiniętej na przełomie XII i XIII wieku (szczególnie intensywnie za pontyfikatu Innocentego III):

Naiwna wizja nienaruszalnej jedności Kościoła i społeczeństwa rozpada się; Kościół
stwarza sobie własną wolną przestrzeń, by móc bez przeszkód wykonywać swoje
specyficzne zadanie duchowe. To odgraniczenie dokonuje się teraz jednakże już nie
w stosunku do społeczności pogańskiej, ale w stosunku do społeczności w znacznym
stopniu schrystianizowanej (przynajmniej zewnętrznie). Stąd też wykształcanie się
własnych struktur Kościoła prowadzi prawie nieuchronnie do przeciwstawienia kultury
chrześcijańsko-duchownej kulturze chrześcijańsko-świeckiej. Skoro Kościół nie chce
być tożsamy z całą chrześcijańską społecznością, tworzy wobec niej kontrast przez to
właśnie, że staje się przede wszystkim tym szczególnym obszarem, którym zawiaduje
papież i jego wikariusze, biskupi i kapłani. (...) Cena, którą zapłacono za wolność
Kościoła, jest (...) wysoka (...); formalne, prawno-polityczne odgraniczenie Kościoła
od państwa prowadzi do coraz silniejszego upodobnienia struktur kościelnych do pań-
stwowych wzorców władzy i porządku (Kehl 1992: 349).

Proces ten również w wewnętrznej praktyce Kościoła oznaczał więc zdwojenie struktur i kultur religijnych: skoro tak jednoznacznie wyłonił się i ukształtował „Kościół duchownych” z własną ,polityką” (w szczególności doboru i kształcenia kleru) i ,estetyką” (w postaci postępującej standaryzacji zachowań, stroju, form życia, ale zwłaszcza prawa kanonicznego, procedur administracyjnych itd.), musiał pojawić się także i „Kościół świeckich", oczywiście podporządkowany temu pierwszemu. Oba stopniowo wykształciły nowe, specyficzne dla obu stanów formy pobożności i religijne struktury. Ten dwukrotnie zduplikowany układ: administracja kościelna i państwowa oraz kościelna organizacja kleru i stanu świeckiego, przetrwa i będzie odtąd stanowił ramę relacji Kościoła do państwa (a także wszelkiego rodzaju organizacji: politycznych, kulturalnych, ekonomicznych, medialnych itp.). Wprawdzie reformacja (a wcześniej ruchy Wicliffa i Husa) będą próbowały zatrzymać te procesy i odrzucić ów podział, ale w stosunku do imperium Kościoła rzymskiego (pomniejszonego, ale nadal wielkiego) próby te okażą się bezskuteczne.

Ukształtowana wówczas, feudalna w swojej konstrukcji, a zarazem administracyjnie wysoce sprawna struktura stanu duchownego okaże się 
głównym atutem Kościoła rzymskiego nie tylko w epoce bezpośrednio poreformacyjnej (jej najwybitniejszą realizacją, dostosowaną zarazem do wyzwań europejskiej i pozaeuropejskiej nowożytności stało się Towarzystwo Jezusowe, ukonstytuowane jako spójna, a zarazem elastyczna nowoczesna papieska armia bez broni), ale jeszcze wyraźniej w następnym momencie węzłowym, zapoczątkowanym konfrontacją $\mathrm{z}$ europejskim oświeceniem i rewolucją, a zamykającym się znalezieniem funkcjonalnej formuły relacji Kościoła do zsekularyzowanego czy wprost politycznie mu wrogiego otoczenia - lub odwrotnie: relacji nowoczesnych państw, najpierw absolutystycznych, potem totalitarnych, wreszcie demokratycznych, do Kościoła, który z trudem akceptuje ich założenia, a ich władzę traktuje - przyznając to lub nie - jako uzurpację.

To ostatnie stwierdzenie może się wydać zbyt radykalne. Spróbuję je wobec tego krótko uzasadnić, analizując ostatni z węzłowych momentów rozwoju relacji Kościoła rzymskiego do państwa.

\section{Węzeł trzeci: imperium urazu}

Chodzi o okres zapoczątkowany „racjonalizacją” relacji państw do Kościoła (taką jak reformy józefińskie w Świętym Cesarstwie Rzymskim Narodu Niemieckiego), charakteryzujący się utratą autorytetu papieskiego w Europie porewolucyjnej i napoleońskiej, a zakończony konfliktem państwa papieskiego w Italii z rodzącym się zjednoczonym państwem włoskim i rozwiązaniem tego konfliktu w postaci traktatów laterańskich (1929). To oczywiście tylko plakatowo zarysowane punkty symboliczne. Istotą rzeczy jest złożony proces emocjonalno-estetyczno-polityczny, który w tym czasie przebiega wewnątrz kościelnej elity administracyjnej.

Tym razem sytuacja zewnątrzpolityczna i emocjonalno-estetyczna Kościoła w punkcie wyjścia tego węzłowego momentu stapiają się w jedno: Kościół po raz kolejny czuje się atakowany, tym razem przez wrogie moce, które w jego świadomości narodziły się z jego własnego łona i próbują przejąć nad nim kontrolę. Odpowiedź jest raz jeszcze nie twórcza, a naśladowcza. Odzwierciedla nowy porządek administracyjno-państwowy, który powstał z działania pokolenia twórców Europy (i Ameryki) pooświeceniowej i rewolucyjnej, o których 
można zapewne w pewnym skrócie powiedzieć, że nie chcieli być kapłanami. Można to powiedzieć najpierw w znaczeniu całkiem dosłownym - warto sobie uświadomić, jak wielu spośród twórców Oświecenia zrezygnowało z kariery duchownej, do której byli mniej lub bardziej wyraźnie kierowani. Chodzi tu jednakże o coś więcej - nie tylko o ewentualny stan duchowny tych czy innych ludzi wybitnych, ale jeszcze bardziej o kapłański typ przywództwa. Ci, którzy teraz przejmują odpowiedzialność, nie chcą w żadnym razie być kapłanami. Chcą być raczej nauczycielami i zarządcami. Moglibyśmy powiedzieć: tylko nauczycielami i tylko zarządcami, ale oni sami w większości wypadków bynajmniej nie odczuwają swojego wyboru jako ograniczenia (Węcławski 1999: 81-82).

Sposób sprawowania władzy w wielkich Kościołach chrześcijańskich, a w Kościele rzymskim w szczególności, dostosowuje się teraz do tego nowego tonu. Również tu na pierwszy plan coraz wyraźniej wysuwa się nauczanie i zarządzanie (a czasem taki rodzaj nauczania, który w istocie jest bardziej zarządzaniem niż nauczaniem). Ludzie Kościoła - nie tylko papieże, ale papieże na pierwszym miejscu - okazują się w znacznym stopniu bezradni wobec tego, co się stało, i to nie tylko bezradni intelektualnie, co stosunkowo łatwo zrozumieć, biorąc pod uwagę ówczesny stan wykształcenia oraz kompetencji kulturowych i politycznych osób duchownych, ale także jako przywódcy religijni. Zarazem też dokonujące się bardzo szybko zmiany cywilizacyjne - gwałtowna industrializacja i jej społeczne skutki (to jest postępująca totalitaryzacja polityki i życia społecznego) szybko podcinają podstawy dotychczasowej formuły zorganizowanego życia religijnego. Na takim tle utrzymuje się, a nawet nasila, ten sam dominujący typ reakcji ludzi odpowiedzialnych za losy Kościoła na pojawiające się kolejno trudności i zagrożenia. Jest to najpierw właśnie nauczanie (a ściśle biorąc: „pompatyczne pouczenie” - wystarczy przyjrzeć się tonowi, estetyce i treści dziewiętnastowiecznych papieskich encyklik), a następnie także zarządzanie (podtrzymywanie kościelnej dyscypliny). Uchwytnym tego wyrazem jest stały wzrost liczby (i jakości) kościelnych dokumentów, a także towarzyszący mu wzrost sprawności administracyjnej kościelnych instytucji - zwłaszcza centralnych. Dla unaocznienia zjawiska przykład z tzw. Syllabusa Piusa IX, wykazu błędnych poglądów, opublikowanego w roku 1864:

Socjalizm, Komunizm, Tajne Stowarzyszenia, Stowarzyszenia Biblijne, Stowarzyszenia klerykalno-liberalne. Tego rodzaju zgubne doktryny bywały często potępiane w najostrzejszych słowach w encyklice Qui pluribus z dnia 9 listopada 1846 roku, 
w przemówieniu Quibus quantisque z dnia 20 kwietnia 1849 roku, w encyklice Noscitis et nobiscum z dnia 8 grudnia 1849 roku, w przemówieniu Singulari quadam z dnia 9 grudnia 1854 roku, w encyklice Quanto conficiamur moerore z dnia 10 sierpnia 1863 roku.

(...)

Kościół od Państwa, a Państwo od Kościoła winno być odłączone.

Przemówienie Acerbissimum z dnia 27 września 1852 roku. (...)

W naszych czasach nie jest już więcej rzeczą pożyteczną, by religia katolicka uważana była jakby za jedyną religię państwa, z wykluczeniem wszystkich pozostałych.

Przemówienie Nemo vestrum z dnia 26 lipca 1855 roku. (...)

Biskup Rzymski może i powinien pogodzić się i uporządkować swoje relacje z postępem, z liberalizmem i współczesną cywilizacją.

Przemówienie Iam dudum cernimus z dnia 18 marca 1861 roku.

(Breviarium fidei 1964: 91)

Najistotniejszą składową wspomnianego wyżej procesu emocjonalno-estetyczno-politycznego, przebiegającego wówczas wewnątrz kościelnej elity administracyjnej, jest uraz, który wynika stąd, że realna władza polityczna w jej klasycznej postaci - rządzenia i panowania uniwersalnego - właśnie została kościelnemu centrum władzy odebrana. Nie naruszyło to jednak fantazmatu kościelnej władzy: jej uniwersalnego roszczenia i jej świadomościowego imperializmu. Efektem są samoświadomość i polityka, które stanowią teraz wypadkową owych dwu składowych: urazu i przekonania o własnej zwierzchności. Czasem dochodzą one do głosu wprost w eksponowaniu własnego uniwersalnego roszczenia - jak dogmat nieomylności papieskiej i imperialne pouczenia kierowane do władz i polityków; warto w tym kontekście przyjrzeć się np. oficjalnej korespondencji cesarza Wilhelma I i papieża Piusa IX (cf. Maron 1972: 200-203). Dalszy rozwój sytuacji zewnętrznej zmusza administrację kościelną do skutecznego maskowania tego roszczenia „dyplomatyczną układnością”. Wyrażana w traktatach, konkordatach, w końcu w akceptacji konstytucyjnych zasad demokracji itd. dyplomatyczna układność pozostaje jednak zewnętrzna w stosunku do realnej kościelnej świadomości władzy. Można powiedzieć obrazowo, że owa imperialna świadomość urzędników Kościoła rzymskiego trwa w gotowości wykorzystania każdej szansy i każdej luki, w którą może wejść, by przekształcić się we władzę realną. Jest ona tym bardziej skuteczna, że jako wewnętrzny fantazmat nie musi być poddawana dyskursowi i ocenie - stanowi „milczący rdzeń” kościelnych działań politycznych, modyfikowanych jedynie w zależności od sytuacji większym lub 
mniejszym natężeniem urazu i odpowiednio mniejszym lub większym dialogowym otwarciem. To właśnie umożliwia sprawne korzystanie z dyplomacji budowanej na podłożu urazu, a sterowanej niezmienionym, a wręcz wzmocnionym ,imperialnym impulsem” Kościoła rzymskiego.

\section{Podsumowanie}

Obserwacje, które tu przedstawiłem, potwierdzają w moim przekonaniu zasadność wstępnej tezy: Kościół rzymski w rdzeniu swojej świadomości nigdy realnie nie uznał w stosunku do siebie zwierzchności żadnej władzy ziemskiej, rozwinął fantazmat, który pozwala mu w zmieniających się - z jego punktu widzenia coraz bardziej niekorzystnie - warunkach zachować rdzeń przekonania o własnej bezwzględnej zwierzchności. Stąd pragmatyczne, a czasem również formalne, uznanie oddzielnych kompetencji władzy państwowej w zakresie, do którego władza kościelna nie rości sobie żadnych pretensji, nigdy natomiast uznanie jej jakichkolwiek kompetencji w stosunku do samego Kościoła. Drugą stroną tej samej pozycji jest wspomniana w ostatniej części mojej wypowiedzi gotowość wchodzenia wszędzie tam, gdzie w polu kompetencji politycznych i społecznych możliwe jest uzyskanie władzy realnej.

\section{Literatura}

Breviarium fidei. Kodeks doktrynalnych wypowiedzi Kościoła, 1964, oprac. J.M. Szymusiak, S. Głowa, Poznań.

Evdokimov P., 1986, Prawostawie, przeł. J. Klinger, Warszawa.

Kehl M., 1992, Die Kirche. Eine katholische Ekklesiologie, Würzburg.

Knowles D., Obolensky D., 1988, Historia Kościoła, t. 2, 600-1500, przeł. R. Turzyński, Warszawa.

Leon Wielki, 1958, Mowy, przeł. K. Tomczak, Poznań.

Maron G., 1972, Die römisch-katholische Kirche von 1870 bis 1970, Göttingen.

Węcławski T., 1999, Wielkie kryzysy tradycji chrześcijańskiej, Poznań. 